DOI: $10.4274 /$ tpa. 1068

\title{
Does maternal anemia affect the newborn?
}

\author{
Banu Dane, Necmi Arslan*, Gonca Batmaz, Cem Dane* * \\ Bezmialem University Department of Gynecology and Obstetrics, Istanbul , Turkey \\ *Haseki Education and Research Hospital, Division of Family Practice, Istanbul, Turkey \\ **Bezmialem University, Department of Gynecology and Obstetrics, Istanbul, Turkey
}

\section{Summary}

Aim: In this study, we aimed to evaluate the effect of maternal anemia on the newborn.

Material and Method: We determined hemoglobin $(\mathrm{Hb})$, hematocrit ( $\mathrm{Hct}$ ) levels of 307 pregnant women who delivered in our clinic and $\mathrm{Hb}$, Hct, bilirubin levels in the cord blood, mode of delivery and Apgar scores of their newborns. The pregnant women were evaluated in two groups according to their $\mathrm{Hb}$ levels with the ones with a $\mathrm{Hb}$ value above $11.1 \mathrm{mg} / \mathrm{dl}$ as the nonanemic group and a $\mathrm{Hb}$ value below $11 \mathrm{mg} / \mathrm{dl}$ as the anemic group. We also created four groups with Hb levels $\geq 11.1 \mathrm{mg} / \mathrm{dl}$, between $11-10.1 \mathrm{mg} / \mathrm{dl}$, between 10-9.1 mg/dl and $\leq 9 \mathrm{mg} / \mathrm{dl}$.

Results: We We included 146 anemic and 161 nonanemic patients in the study. The rate of delivery of babies with low birth weight was significantly higher in the anemic group ( $11.6 \%$ vs. $4.3 \%, \mathrm{P}=0.029)$. The rate of low birth weight was significantly higher in the patients

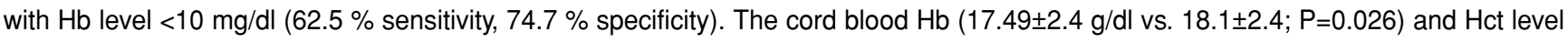
( $53.3 \pm 7.4 \%$ vs. $55.6 \pm 7.2 \% ; P=0.006)$ in the anemic group were significantly lower.

Conclusions: Anemia in pregnancy increases the risk of low birth weight and lowers the levels of $\mathrm{Hb}$ and Hct of the newborn. Anemia should be screened and treated before delivery. (Turk Arch Ped 2013; 48: 195-199)

Key words: Anemia, hemoglobin, low birth weight, newborn

\section{Introduction}

Presence of anemia during pregnancy and after pregnancy is a common problem which has significant effects on the mother and developing baby (1). It has been reported that low maternal hemoglobin level increases the risk of low birth weight, premature delivery and small for gestational age baby $(2,3)$. Small for gestational age babies constitute a significant portion of neonatal morbidity and mortality. Although these babies constitute $6-7 \%$ of newborns, $2 / 3$ of all neonatal deaths occur in this group $(4,5)$. In many studies including pregnant women with iron deficiency anemia, iron supplement has been shown to improve birth weight and decrease the mortality rate $(6,7)$.

The iron storage of the newborn baby may depend on the iron status of the mother. In many studies, it was found that iron deficiency during pregnancy affected fetal iron stores (8-10). It is recommended to start iron supplements before pregnancy, if possible or in the early pregnancy to prevent the effects of iron deficiency on the fetus and newborn (6).

In this study, we aimed to determine the problems related with the mode of delivery and the newborn as a result of anemia before delivery in pregnant women who delivered in our clinic.

\section{Material and Method}

307 subjects among the pregnant women who delivered in our clinic between June 2009 and October 2009 were included in the study. The data were collected by obtaining information related with the mother and newborn from delivery room and computer records. The study exclusion 
criteria were as follows: multiple pregnancy, preeclampsia premature seperation of placenta and placenta previa with hemorrhage and fetal anomaly. The maternal age, gravida parity and mode of delivery, birth weight of newborn and Apgar scores at the first and fifth minutes were determined from the records of the delivery room for each mother. In routine practice of our clinic, a 2 cc blood sample is obtained from pregnant women for hemogram when they present for delivery and a $2 \mathrm{cc}$ blood sample is obtained from the umbilical cord after delivery. The samples are placed in $2 \mathrm{cc}$ EDTA tubes and are processed in 2 hours in our emergency laboratory. Hemoglobin $(\mathrm{Hb})$ and hematocrite $(\mathrm{Hct})$ values obtained as a result of hemogram are recorded seperately for the mother and baby. At the 6-8th hour postnatally, 1 cc blood is obtained from the newborn and placed in a dry tube containing gel. Total bilirubin value is determined using Abbot's 16000 colorometric method. The results are recorded in the hospital computer program.

Based on the hemoglobin levels, the subjects were divided into two groups as the ones with a $\mathrm{Hb}$ value of $\leq 11$ $\mathrm{g} / \mathrm{dL}$ (146 anemic subjects) and a $\mathrm{Hb}$ value of $\geq 11,1 \mathrm{~g} / \mathrm{dL}$ (161 nonanemic subjects). A birth weight of $\leq 2500 \mathrm{~g}$ was considered low for gestational age (LGA) and an Apgar score of $<7$ at the fifth minute was considered low Apgar score.

Med Calc program was used in the statistical analysis of the study. The results were expressed as mean \pm standard deviation. Independent $T$ test was used for comparison of the groups and chi-square and Fisher's exact test was used for evaluation of non-numerical data. Prediction of presence of LGA with maternal $\mathrm{Hb}$ was evaluated using Roc curve. A $p$ value of $<0,05$ was considered statistically significant in all assessments.

\section{Results}

307 subjects 146 of whom were anemic and 161 of whom were nonanemic were included in the study. The mean maternal $\mathrm{Hb}$ value was $11.07 \pm 1.5 \mathrm{~g} / \mathrm{dL}$ and $\mathrm{Hct}$ value was $\% 33,9 \pm 4,5$.
No significant difference was found between he anemic and nonanemic groups in terms of maternal age, gravida, parity and delivery by cesarean section (Table1).

While no difference was found between the groups in terms of mean birth weight, the rate of LGA subjects was significantly higher in the anemic group (11.6\% vs $4.3 \%$; $\mathrm{P}=0,02$ ). There was no difference between the groups in terms of mean Apgar scores at the first and fifth minutes. The number of the subjects with a low Apgar score at the fifth minute did not show significant difference. The results are shown in Table 2.

It was found that the mean $\mathrm{Hb}(17.49 \pm 2.4 \mathrm{~g} / \mathrm{dL}$ vs $18.1 \pm 2.4 \mathrm{~g} / \mathrm{dL} ; \mathrm{P}=0.026)$ and Hct values $(53.3 \% \pm 7.4$ vs $55.6 \% \pm 7.2 ; p=0.006$ ) of the newborns in the anemic group were significantly low. The mean bilirubin values of the newborns did not show significant difference between the two groups. The results are shown in Table 3.

The anemic subjects were divided into three groups according to $\mathrm{Hb}$ values: the first group had $\mathrm{a} \mathrm{Hb}$ value of $11-10.1 \mathrm{~g} / \mathrm{dL}$ ( $\mathrm{n}: 59)$, the second group had a $\mathrm{Hb}$ value of $10-9.1 \mathrm{~g} / \mathrm{dL}(\mathrm{n}: 60$ ) and the third group had a $\mathrm{Hb}$ value of $\leq 9 \mathrm{~g} / \mathrm{dL}$ ( $\mathrm{n}: 27$ ). The rate of cesarean section and the mean birth weight in these three anemic subgroups with different $\mathrm{Hb}$ values were not different from the nonanemic group. The frequency of LGA subjects was significantly higher in the two groups with a $\mathrm{Hb}$ value of $\leq 10 \mathrm{~g} / \mathrm{dL}$ compared to the nonanemic group. No significant difference was found between the groups in terms of the rate of the subjects with a low Apgar score at the fifth minute. The results are shown in Table 4.

Maternal $\mathrm{Hb}$ values and presence of LGA in the newborn were evaluated using Roc curve (Picture 1). It was found that the frequency of LGA increased significantly when the $\mathrm{Hb}$ value was $\leq 10 \mathrm{~g} / \mathrm{dL}(62.5 \%$ sensitivity, $74.7 \%$ specificity).

It was found that the mean cord blood $\mathrm{Hb}(17.3 \pm 3 \mathrm{~g} /$ $\mathrm{dL}$ vs $18.1 \pm 2.4 \mathrm{~g} / \mathrm{dL} ; \mathrm{P}<0.05)$ and $\mathrm{Hct}(52.8 \% \pm 6.7$ vs $55.6 \% \pm 7.2$ ) values were significantly lower in the group with a maternal $\mathrm{Hb}$ value of $11-10,1 \mathrm{~g} / \mathrm{dL}$ compared to the nonanemic group. The mean bilirubin value of the newborn did not show significant difference. The results are shown in Table 5.

Table 1. Comparison of anemic pregnant women with nonanemic pregnant women in terms of maternal age, gravida, parity and mode of delivery

\begin{tabular}{|l|c|c|c|}
\hline & $\mathbf{H b} \leq \mathbf{1 1} \mathbf{~ g / d L}$ & $\mathbf{H b} \geq \mathbf{1 1 . 1} \mathbf{~ g / d L}$ (n: 161) & $\mathbf{p}$ value \\
\hline Maternal age (mean \pm SD) & $(\mathrm{n}: 146)$ & $\mathrm{Hb} \geq 11.1 \mathrm{~g} / \mathrm{dL}$ & 0.87 \\
\hline Gravida (mean $\pm S D)$ & $2.74 \pm 1.74$ & $2.52 \pm 1.62$ & 0.25 \\
\hline Parity (mean \pm SD) & $2.39 \pm 1.37$ & $2.23 \pm 1.24$ & 0.28 \\
\hline Delivery by cesarean section (\%) & 31.5 & 22.9 & 0.11 \\
\hline
\end{tabular}




\section{Discussion}

Anemia is a real public health problem especially in developing countries. The rate of anemia in women of child-bearing age in our country has been reported to be $32.8-40 \% \quad(11,12)$. In studies performed in pregnant women in different countries, the frequency of anemia ranges between $32.6 \%$ and $80 \%(13,14,15)$. In pregnant women included in our study, the rate of anemia was found to be $44.8 \%$.

Kilbride et al. (16) found the maternal $\mathrm{Hb}$ concentration to be $12.2 \pm 0.9 \mathrm{~g} / \mathrm{dL}$ and $9.9 \pm 0.7 \mathrm{~g} / \mathrm{dl}$ in the normal and anemic groups, respectively. Okuyamo et al. (17) found these values to be $11.7 \pm 0.8 \mathrm{~g} / \mathrm{dL}$ and $9.8 \pm 1.1 \mathrm{~g} / \mathrm{dL}$. In our study, the mean $\mathrm{Hb}$ value was found to be $11.07 \pm 1.5$ $\mathrm{g} / \mathrm{dL}$ and the mean Hct value was found to be $33.9 \% \pm 4.5$ in pregnant women. The mean $\mathrm{Hb}$ value was found to be $9.7 \pm 0.9 \mathrm{~g} / \mathrm{dL}$ in the anemic group and $12.3 \pm 0.8 \mathrm{~g} / \mathrm{dL}$ in the nonanemic group.

The difference between the mean birth weight values in babies of anemic mothers ( $3251 \pm 491 \mathrm{~g}$ ) and nonanemic mothers (3 $251 \pm 491 \mathrm{~g})$ was not significant. However, the rate of LGA was $11,6 \%$ in the anemic group and $4,3 \%$ in the nonanemic group. The difference was statisticslly significant $(P=0.029)$.

\section{Table 2. Comparison of anemic pregnant women with nonanemic pregnant women in terms of results of the newborn}

\begin{tabular}{|c|c|c|c|}
\hline & $\mathrm{Hb} \leq 11 \mathrm{~g} / \mathrm{dL}$ & $\mathrm{Hb} \geq 11.1 \mathrm{~g} / \mathrm{dL}(\mathrm{n}: 161)$ & p değeri \\
\hline Birth weight $(\mathrm{g})($ mean $\pm S \mathrm{D})$ & $3243 \pm 621$ & $3251 \pm 491$ & 0.9 \\
\hline Low birth weight $(n)$ & $17(\% 11.6)$ & $7(\% 4,3)$ & 0.029 \\
\hline Apgar (1st min) (mean $\pm S D)$ & $8.5 \pm 1.15$ & $8.3 \pm 1.3$ & 0.15 \\
\hline Apgar (5 $\left.5^{\text {th }} \mathrm{min}\right)($ mean $\pm S D)$ & $9.7 \pm 0.72$ & $9.6 \pm 0.69$ & 0.21 \\
\hline Apgar $<7$ (5th $\min )(n)$ & 3 & 3 & 1 \\
\hline
\end{tabular}

\begin{tabular}{|l|c|c|c|}
\hline \multicolumn{4}{|c|}{ Table 3. Comparison of mean cord blood $\mathbf{H b}$ and Hct values and neonatal bilirubin values } \\
\hline & $\mathbf{H b} \leq \mathbf{1 1} \mathbf{~ g / d L}$ & $\mathbf{H b} \mathbf{1 1 . 1} \mathbf{~ g / d L}$ (n:161) & $\mathbf{p}$ değeri \\
\hline Cord blood $\mathrm{Hb}(\mathrm{g} / \mathrm{dL})(\mathrm{mean} \pm \mathrm{SD})$ & $17.49 \pm 2.4$ & $18.1 \pm 2.4$ & 0.026 \\
\hline Cord blood $\mathrm{Hct}(\%)(\mathrm{mean} \pm \mathrm{SD})$ & $53.3 \pm 7.4$ & $55.6 \pm 7.2$ & 0.006 \\
\hline Neonatal bilirubin $(\mathrm{mg} / \mathrm{dL})(\mathrm{mean} \pm \mathrm{SD})$ & $4.9 \pm 2.6$ & $5.1 \pm 2.5$ & 0.49 \\
\hline
\end{tabular}

Table 4. Comparison of the results of the newborns between the groups with different $\mathrm{Hb}$ values and the nonanemic group

\begin{tabular}{|c|c|c|c|c|}
\hline & $\begin{array}{c}\mathrm{Hb} \geq 11.1 \mathrm{~g} / \mathrm{dL} \\
(\mathrm{n}: 161)\end{array}$ & $\begin{array}{c}\mathrm{Hb}=11-10.1 \mathrm{~g} / \mathrm{dL} \\
(\mathrm{n}: 59)\end{array}$ & $\begin{array}{c}H b=10-9.1 \mathrm{~g} / \mathrm{dL} \\
(\mathrm{n}: 60)\end{array}$ & $\begin{array}{c}\mathrm{Hb} \leq 9 \mathrm{~g} / \mathrm{dL} \\
(\mathrm{n}: 27)\end{array}$ \\
\hline Cesarean section & $37(\% 22.9)$ & $18(\% 30.5)$ & $19(\% 31.6)$ & 9 (\%33.3) \\
\hline Birth weight (g) & $3243 \pm 621$ & $3301 \pm 455$ & $3298 \pm 617$ & $2990 \pm 863$ \\
\hline Low birth weight & $\% 4.3$ & $\% 3.4$ & $\% 13.3^{*}$ & $\% 25.9^{*}$ \\
\hline Apgar $\left(5^{\text {th }} \min \right)<7$ & $\% 1.8$ & $\% 1.7$ & $\% 3.7$ & 0 \\
\hline
\end{tabular}

$p<0.05$

Table 5. Comparison of cord blood $\mathrm{Hb}$ and Hct values and neonatal bilirubin values between the groups with different $\mathrm{Hb}$ values and the nonanemic group

\begin{tabular}{|l|c|c|c|c|}
\hline & $\begin{array}{c}\mathbf{H b} \geq \mathbf{1 1 . 1} \mathbf{~ g / d L} \\
(\mathbf{n}: \mathbf{1 6 1})\end{array}$ & $\begin{array}{c}\mathbf{H b}=\mathbf{1 1 - 1 0 . 1} \mathbf{~ g / d L} \\
(\mathbf{n}: 59)\end{array}$ & $\begin{array}{c}\mathbf{H b}=\mathbf{1 0 - 9 . 1} \mathbf{~ g / d L} \\
(\mathbf{n}: 60)\end{array}$ & $\begin{array}{c}\mathbf{H b} \leq \mathbf{9} \mathbf{~ g / d L} \\
\mathbf{( n : 2 7 )}\end{array}$ \\
\hline Cord blood Hb (g/dL) & $18.1 \pm 2.4$ & $17.3 \pm 2.2^{*}$ & $17.5 \pm 1.8$ & $17.5 \pm 3.6$ \\
\hline Cord blood Hct (\%) & $55.6 \pm 7.2$ & $52.8 \pm 6.7^{*}$ & $53.1 \pm 5.6$ & $53.2 \pm 11$ \\
\hline Neonatal bilirubin (mg/dL) & $5.1 \pm 2.5$ & $4.9 \pm 2$ & $5.1 \pm 3.1$ & $4.3 \pm 2.7$ \\
\hline
\end{tabular}




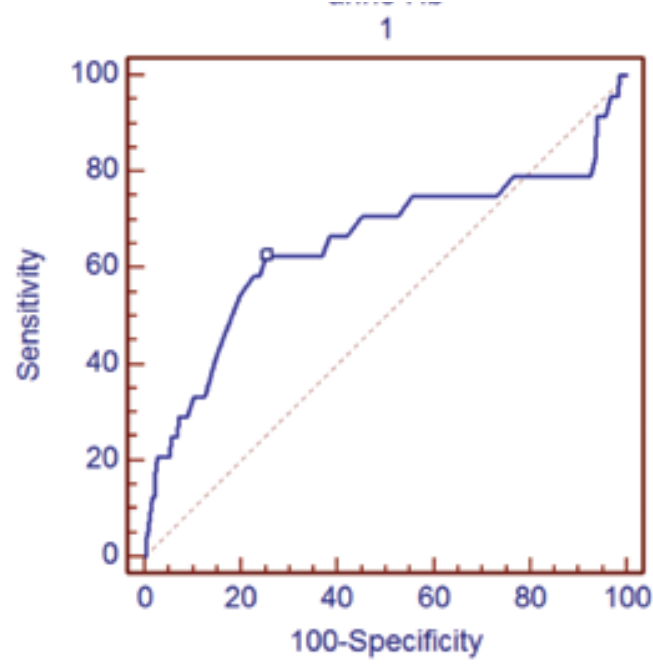

Picture 1. Roc curve correlating maternal $\mathrm{Hb}$ values with presence of low birth weight (AUC 0.65; $P=0.0045$ )

The rates of LGA were observed to be $4.3 \%, 3.4 \%$, $13.3 \%$ and $25.9 \%$ in the groups with a maternal $\mathrm{Hb}$ level of $\geq 11.1 \mathrm{~g} / \mathrm{dL}, 11-10.1 \mathrm{~g} / \mathrm{dL}, 10-9.1 \mathrm{~g} / \mathrm{dL}$ and $\mathrm{Hb} \leq 9 \mathrm{~g} / \mathrm{dL}$, respectively.

The increase in the rates of LGA with the decrease in maternal $\mathrm{Hb}$ values was significant especially in the two groups with a $\mathrm{Hb}$ value below $10 \mathrm{~g} / \mathrm{dL}$. Compatible with our findings, Malhotra et al. (13) found that severe anemia was correlated with delivery of LGA baby in the study they performed by dividing anemic mothers into three groups (mild; $\mathrm{Hb}: 9-10.9 \mathrm{~g} / \mathrm{dL}$, moderate; $\mathrm{Hb}: 7-8.9 \mathrm{~g} / \mathrm{dL}$, severe; $\mathrm{Hb}<7 \mathrm{~g} / \mathrm{dL}$ ). Kozuki et al. (18) reported that moderate or severe anemia in the mother $(<90 \mathrm{~g} / \mathrm{L}-$ or $<80 \mathrm{~g} / \mathrm{L})$ increased the risk of delivery of LGA baby by $53 \%$ as a result of a metaanalysis they performed. However, as the same authors stated, the fact that different threshold values were used in the studies examining the effects of maternal anemia on the fetus and newborn makes it difficult to make a joint evaluation.

In case of high maternal $\mathrm{Hb}$ level $(>12 \mathrm{~g} / \mathrm{dL}$ or $>13$ $\mathrm{g} / \mathrm{dL}$ ), birth weight of the newborn has been shown to decrease and the risk of preeclampsia has been shown to increase $(19,20)$. Interestingly, presence of high numbers of hypochromic red cells has been reported to cause to an increase in birth weight by prolonging the pregnancy (21). In addition, mild maternal anemia ( $\mathrm{Hb}: 9-10.9 \mathrm{~g} / \mathrm{dL})$ was found to be related with LGA or intrauterine growth retardation, stillbirth or neonatal mortality, induction of delivery or cesarean section with the lowest rate (13). Similarly, LGA was found with the lowest rate (3.4\%) in the group with mild maternal anemia $(\mathrm{Hb}: 10.1-11 \mathrm{~g} / \mathrm{dL})$ in our study. Iron or iron+folic acid supplements in the prenatal period prevent iron deficiency and anemia. However, appropriate doses should be determined to prevent hemoconcentration which is a side effect the outcomes of which can not be predicted clearly (22).

In a study performed by El-Farrash et al. (10), Hb, red cell indexes and iron levels were directly proportional with maternal $\mathrm{Hb}$, iron and ferritin levels in babies of the mothers with moderate and severe anemia compared to babies of mothers with normal $\mathrm{Hb}$ values. In our group, the mean $\mathrm{Hb}$ value was found to be $17,8 \pm 2,4 \mathrm{~g} / \mathrm{dL}$ and the mean Hct value was found to be $54,5 \% \pm 7,3$ in the chord blood. When $\mathrm{Hb}$ values in the cord blood samples of normal and anemic pregnant women were compared, the results in the groups with $\mathrm{Hb}$ values of $\geq 11,1 \mathrm{~g} / \mathrm{dL}, 11-10.1 \mathrm{~g} / \mathrm{dL}$, $10-9.1 \mathrm{~g} / \mathrm{dL}$ and $\mathrm{Hb} \leq 9 \mathrm{~g} / \mathrm{dL}$ were found to be $18.1 \pm 2.4$, $17.3 \pm 2.2, \quad 17.5 \pm 1.8$ and $17,5 \pm 3,6 \mathrm{~g} / \mathrm{dL}$, respectively. Hematocrit values were found to be $55,6 \% \pm 7.2,52,8 \pm 6.7$, $53.1 \% \pm 5.6$ and $53.2 \% \pm 11$, respectively. Cord blood $\mathrm{Hb}$ and Hct values were significantly lower especially in the group with a maternal $\mathrm{Hb}$ value of 10.1-11 $\mathrm{g} / \mathrm{dL}$ compared to the nonanemic group.

In a study performed in our country, iron deficiency was found in $50 \%$ of anemic pregnant women, vitamin B12 deficiency was found in $34.5 \%$ and folat deficiency was found in $34,5 \%$. The majority of the anemias (56.5\%) are normochromic-normocytic showing mixed anemia (23). The factors for prediction of anemia include low income status, being in the third trimester and having four or more living children. In addition, $\beta$-thalassemia carrier status is observed commonly in our country, though it shows regional variance (24). The limitations of our study included the facts that maternal vitamin levels could not be determined, because the study was a retrospective study, the socioeconomical states of the subjects were not recorded and anemic subjects were not evaluated in terms of $\beta$-thalassemia carrier status.

In this study, we found that the rate of delivery of a LGA baby was increased and cord blood $\mathrm{Hb}$ and Hct values were significantly low in anemic pregnant women. It was also reported that the risk of anemia (OR: 3,68 ) in the 4-6th months in LGA babies of these mothers was higher compared to the babies with a normal birth weight (OR: 1.81) (25). It was shown that anemic mothers could not achieve adequate iron levels in the first six months after delivery and their babies were anemic $(\mathrm{Hb}<11 \mathrm{~g} / \mathrm{dL})$ in the first year with a rate of $81 \%$ (26). Anemic mothers would probably be also anemic in the lactation period. Considering that iron deficiency during infancy affects neurological development negatively, measures should be taken in terms of anemia in these newborns also during infancy $(27,28)$. Anemia should be screened and treated during pregnancy because of its possible negative outcomes.

\section{Conflict of interest: None declared}




\section{Kaynaklar}

1. Breymann C, Bian XM, Blanco-Capito LR, Chong C, Mahmud $G$, Rehman R. Expert recommendations for the diagnosis and treatment of iron-deficiency anemia during pregnancy and the postpartum period in the Asia-Pacific region. Perinat Med 2011; 39: 113-121.

2. Ren A, Wang J, Ye RW, Li S, Liu JM, Li Z. Low first-trimester hemoglobin and low birth weight, preterm birth and small for gestational age newborns. Int J Gynaecol Obstet 2007; 98: 124128.

3. Levy A, Fraser D, Katz M, Mazor M, Sheiner E. Maternal anemia during pregnancy is an independent risk factor for low birthweight and preterm delivery. Eur J Obstet Gynecol Reprod Biol 2005; 122: $182-186$.

4. Guyer B, Freedman MA, Strobino DM , Sondik EJ. Annual summary of vital stastistics: trends in the health of Americans during the 20th century. Pediatrics 2000; 106: 1307-1317.

5. Sumits T, Bennett R, Gould J. Maternal risks for very low birth weight infant mortality. Pediatrics 1996; 98: 236-241.

6. Ribot B, Aranda N, Viteri F, Hernandez-Martinez C, Canals J, Ariia $\mathrm{V}$. Depleted iron stores without anaemia early in pregnancy carries increased risk of lower birthweight even when supplemented daily with moderate iron. Hum Reprod 2012; 27: 1260-1266.

7. Persson LÅ, Arifeen S, Ekström EC, Rasmussen KM, Frongillo EA, Yunus M; MINIMat Study Team. Effects of prenatal micronutrient and early food supplementation on maternal hemoglobin, birth weight, and infant mortality among children in Bangladesh: the MINIMat randomized trial. JAMA 2012; 307: 2050-2059.

8. Singla PN, Tyagi M, Shankar R, Dash D, Kumar A. Fetal iron status in maternal anemia. Acta Paediatr 1996; 85: 1327-1330.

9. Kumar A, Rai AK, Basu S, Dash D, Singh JS. Cord blood and breast milk iron status in maternal anemia. Pediatrics 2008; 121 : 673-637.

10. El-Farrash RA, Ismail EA, Nada AS. Cord blood iron profile and breast milk micronutrients in maternal iron deficiency anemia. Pediatr Blood Cancer 2012; 58: 233-238.

11. Pala K, Dündar N. Prevalence \& risk factors of anaemia among women of reproductive age in Bursa, Turkey. Indian J Med Res 2008; 128: 282-286.

12. Kılınç $M$, Yüregir GT, Ekerbiçer $H$. Anaemia and iron-deficiency anaemia in south-east Anatolia. Eur J Haematol 2002; 69: 280283.

13. Malhotra M, Sharma JB, Batra S, Sharma S, Murthy NS, Arora R. Maternal and perinatal outcome in varying degress of anemia. Int J Gynecol Obstet 2002; 79: 93-100.

14. Zhang Q, Li Z, Ananth CV. Prevalence and risk factors for anaemia in pregnant women: a population - based prospective cohort study in China. Paediatr Perinat Epidemiol 2009; 23: 282-291.
15. Sharma A, Patnaik R, Garg S. Prema Ramachandran. Detection \& management of anaemia in pregnancy in an urban primary health care institution. İndian J Med Res 2008; 128: 45-51.

16. Kilbride J, Baker TG, Parapia LA, Khoury SA. Iron status, serum folate and $B(12)$ values in pregnancy and postpartum: report from a study in Jordan. Ann Saudi Med 2000; 20: 371-376.

17. Okuyama T, Tawada T, Furuya $\mathrm{H}$, Villee $\mathrm{CA}$. The role of transferin and ferritin in the fetal-maternal-placental unit. Am J Obstet Gynecol 1985; 152: 344-350.

18. Kozuki N, Lee AC, Katz J, Child Health Epidemiology Reference Group. Moderate to severe, but not mild, maternal anemia is associated with increased risk of small-for-gestational-age outcomes. J Nutr 2012; 142: 358-362.

19. Steer JP. Maternal hemoglobin concentration and birth weight. Am J Clin Nutr 2000; 71: 1285-1287.

20. Sekhavat L, Davar R, Hosseinidezoki S. Relationship between maternal hemoglobin concentration and neonatal birth weight. Hematology 2011; 16: 373-376.

21. Ervasti M, Sankilampi U, Heinonen S, Punnonen K. Early signs of maternal iron deficiency do not influence the iron status of the newborn, but are associated with higher infant birthweight. Acta Obstet Gynecol Scand 2009; 88: 83-90.

22. Pena-Rosas JP, Viteri FE. Effects and safety of preventive oral iron or iron+folic acid supplementation for women during pregnancy. Cochrane Database Syst Rev 2009; CD 004736.

23. Karaoglu L, Pehlivan E, Egri M, et al. The prevalence of nutritional anemia in pregnancy in an east Anatolian province, Turkey. BMC Public Health 2010;10: 329.

24. Guvenc B, Canataroglu A, Unsal C, Yildiz SM, Turhan FT, Bozdogan ST, Dincer S, Erkman H. -thalassemia mutations and hemoglobinopathies in Adana, Turkey: results from a single center study. Arch Med Sci 2012; 8: 411-414.

25. De Pee S, Bloem MW, Sari M, Kiess L, Yip R, Kosen S. The high prevalence of low hemoglobin concentration among Indonesian infants aged 3-5 months is related to maternal anemia. J Nutr 2002; 132: 2215-2221.

26. Kilbride J, Baker TG, Parapia LA, Khoury SA, Shuqaidef SW, Jerwood $D$. Anemia during pregnancy as a risk factor for irondeficiency anemia in infancy, a case-control study in Jordan. Int $\mathrm{J}$ Epidemiol 1999; 28: 461-468.

27. Lozoff B. Early iron deficiency has brain and behavior effects consistent with dopaminergic dysfunction. J Nutr 2011; 141: 740746.

28. Roncagliolo M, Garrido M, Walter T, Peirano P, Lozoff B. Evidence of altered central nervous system development in infants with iron deficiency anemia at 6 mo: delayed maturation of auditory brainstem responses. Am J Clin Nutr 1998; 68: 683-690. 